\title{
Helsepedagogisk kompetanse, læring og mestring
}

\section{FORFATTERE}

Andre Vågan

Seniorforsker

Nasjonal kompetansetjeneste for læring og mestring innen helse (NK LMH)

\section{Kari Eika}

Seniorforsker

Nasjonal kompetansetjeneste for læring og mestring innen helse (NK LMH)

Helge Skirbekk

Førsteamanuensis

Lovisenberg diakonale høgskole

\section{SAMMENDRAG}

Bakgrunn: Helsepedagogisk kompetanse hos fagpersoner som gir lærings- og mestringstilbud til personer med langvarige helseutfordringer, er i liten grad omtalt og diskutert, verken i nordisk eller i internasjonal forskningslitteratur.

Hensikt: Hensikten med studien er å gi en systematisk litteraturoversikt over studier som beskriver sentral helsepedagogisk kompetanse. Vi inkluderte både kvantitative og kvalitative studier samt en systematisk litteraturoversikt.

Metode: Vi gjorde et systematisk litteraturs $\varnothing \mathrm{k}$ i Medline, Embase, PsychInfo og Cinahl etter ulike typer studier som beskriver helsepedagogisk kompetanse i lærings- og mestringstilbud.

Resultat: Studiene beskriver seks kompetanseområder som viktige for at helsepersonell skal kunne gi pasienter og brukere et godt utbytte av lærings- og mestringstilbud. Disse kompetanseområdene er følgende: kunnskaper og ferdigheter knyttet til gruppeledelse, sykdom og diagnose, kommunikasjon, mestring og mestringsstrategier, pedagogikk samt personlige egenskaper og holdninger. Studiene er av varierende kvalitet.

Konklusjon: Studiene fremhever at helsepedagogisk kompetanse er avgjørende for at pasienter og brukere skal kunne få utbytte av lærings- og mestringstilbud. Det er behov for mer forskning av høy kvalitet samt behov for å styrke kvaliteten ytterligere på helsepedagogiske opplæringstiltak og utdanning av studenter, fagpersoner og brukerrepresentanter. 
sykdommer og langvarige helseutfordringer, som for eksempel hjerte- og karsykdommer, type 2-diabetes, overvekt eller fedme, KOLS og kreft (1). Økningen i antall personer som lever med slike utfordringer, skyldes blant annet medisinske fremskritt, nye levevaner og lengre levetid. Pasienter med kroniske lidelser, brukere og pårørende må lære å mestre helseproblemer, symptomer og behandling i dagliglivet. Disse utfordringene kan ikke løses med behandlende tiltak, korte innleggelser og polikliniske kontakter med spesialisthelsetjenesten.

Lærings- og mestringstjenester har et annet mål enn å skulle behandle ved at de skal styrke handlingsevnen til den enkelte pasient eller pårørende. Norske helsemyndigheter vektlegger da også at lærings- og mestringstilbud, både i spesialist- og kommunehelsetjenesten, er avgjørende for å lære å leve med langvarige helseproblemer (2). Lærings- og mestringstilbud forstås her som tilbud eller tiltak som gir støtte og veiledning for å styrke den enkeltes evne til å leve med langvarige helseutfordringer (3). I denne systematiske oversikten fokuserer vi på gruppebaserte tilbud hvor brukermedvirkning er integrert.

Det finnes en rekke internasjonale litteraturoversikter som systematiserer forskning på effekten av lærings- og mestringstilbud med henholdsvis biologiske, psykologiske og atferdsmessige utfallsmål $(4,5)$. I Norge har Kunnskapssenteret for helsetjenesten publisert litteraturoversikter og omtaler av tilgjengelig forskning. Oversiktene viser at kvaliteten på studiene av gruppebaserte lærings- og mestringstilbud og tilbud med brukermedvirkning varierer, men at slike tilbud likevel kan ha positive effekter $(3,6,7)$.

Det er foreløpig lite forskning som dokumenterer hva slags kompetanse som er viktig for å styrke læring og mestring, og på hvilken måte.

Lærings- og mestringstilbud fordrer helsepedagogisk kompetanse (8-10). I Norge har lærings- og mestringssentre i spesialisthelsetjenesten støttet helsepedagogiske opplæringstilbud for fagpersoner og brukerrepresentanter som tilbyr slike tjenester (11). Helsepedagogikk er imidlertid et relativt nytt fagfelt, og det er foreløpig lite forskning som dokumenterer hva slags kompetanse som er viktig for å styrke læring og mestring, og på hvilken måte. I motsetning til profesjonsforskning innen sykepleie, medisin og psykologi (12-14) er det mangel på studier av utøvereffekten i lærings- og mestringstilbud, det vil si studier av hvilken rolle egenskaper ved fagpersoner spiller for utfallet av slike tilbud. Det er også mangel på studier av sentral kompetanse hos fagpersoner $(9,15)$.

\section{HENSIKT}

For å klargjøre hva som er nødvendig kompetanse blant helsepersonell for å styrke læring og mestring blant brukere, har vi derfor systematisk gjennomgått forskningslitteratur. Her presenterer vi forskningslitteratur som omtaler hvilken kompetanse helsepersonell må ha for å kunne gi gode gruppebaserte lærings- og mestringstilbud.

\section{METODE}

Et viktig formål med denne studien er å få en oversikt over hvilke typer studier som finnes på temaet. Siden forskning på temaet er begrenset og lite omtalt, valgte vi å inkludere både kvantitative og kvalitative studier. For at vi skulle inkludere studiene, måtte de ta opp betydningen av helseprofesjonenes kompetanse knyttet til gjennomf $\varnothing$ ring av gruppebaserte lærings- og mestringstilbud, hvor brukermedvirkning er et viktig element. Artiklene var internasjonale artikler skrevet på engelsk med en studiepopulasjon i aldersgruppen 18+. 
Embase (Ovid), PsychInfo (Ovid) og Cinahl (Ebsco) i perioden fra 1. januar 2005 til 1. februar 2015. Søkene ble gjort med følgende nøkkelord, i ulike kombinasjoner: kroniske lidelser (chronic illness), pasientutdanning (patient education), profesjonell kompetanse (professional competence), pasienterfaring (patient experience or satisfaction), gruppeorienterte tiltak (group processes) og brukermedvirkning (patient participation).

Førsteforfatter foretok en første grovsortering av titler og abstrakter. Deretter foretok førsteforfatter og medforfattere en ny og uavhengig gjennomgang av 103 titler og abstrakter $i$ henhold til inklusjons- og eksklusjonskriteriene. Vi løste uoverensstemmelser gjennom diskusjon. Dernest innhentet førsteforfatter fulltekstversjoner av 80 studier. 63 studier ble ekskludert, i all hovedsak fordi de ikke spesifikt tematiserte kompetanse. Førsteforfatter hentet så ut følgende data fra 17 foreløpig inkluderte studier: forfatter, hensikt, design, utvalg og kompetanse.

Forfatterne vurderte deretter, uavhengig av hverandre, kvaliteten på de inkluderte studiene. Med utgangspunkt i Kunnskapssenterets håndbok (16) ble studiene vurdert opp mot sjekklister som var spesifikke for studier med ulik design. I alt 16 studier tilfredsstilte inklusjons- og kvalitetskriteriene og ble inkludert i oversikten (figur 1).

Figur 1: Flytdiagram over litteratursøk

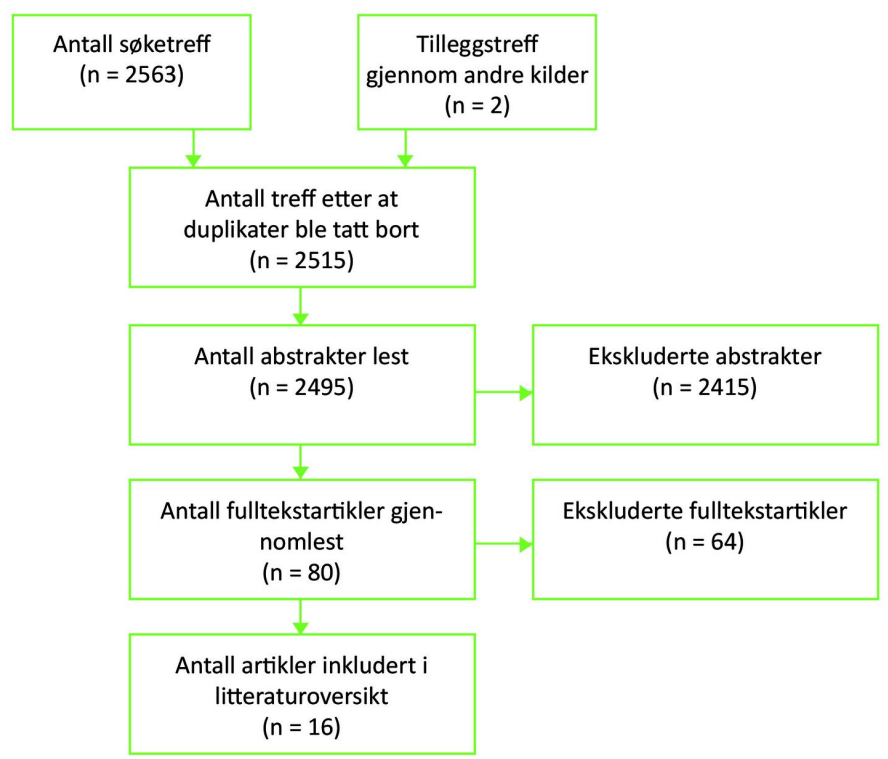

Det finnes ulik begrepsbruk og flere forståelser av profesjonell kompetanse og kunnskap i forskningslitteraturen (17). I denne systematiske oversikten har vi lagt til grunn en bred forståelse av kompetansebegrepet, som inkluderer teoretiske kunnskaper, yrkesspesifikke ferdigheter og holdninger samt personlig kompetanse (18). Med personlig kompetanse mener vi holdninger, verdier, erfaringer og væremåter som kjennetegner den enkelte, som for eksempel kontaktevne, evnen til å være oppmerksomt til stede og evnen til empati (18) Denne brede forståelsen vektlegges både i helse- og sosialfaglige utdanninger og yrkesutøvelse og i litteratur om pasient- og pårørendeopplæring og læring og mestring (19, 20).

En kvantitativ og kvalitativ innholdsanalyse ble gjort av studienes beskrivelser av kompetanse (21). Dette innebar en nedtegnelse og opptelling av de kompetansene som eksplisitt beskrives i studiene. Det innebar også en kodeprosess der vi nedtegnet, kategoriserte og systematiserte meningsinnholdet i setninger og avsnitt i studiene som mer indirekte beskriver kompetanse, i overordnete kategorier. Vi har valgt å presentere 
resultatene av litteraturgjennomgangen med utgangspunkt i sentrale temaer fra denne innholdsanalysen. Analysen peker på hvilke former for kompetanse som vektlegges $\mathrm{i}$ litteraturen, og da på tvers av studiedesign og problemstilling. For å gi en mer samlet og oversiktlig fremstilling har vi gruppert studiene etter studiedesign i tillegg til forfatter, hensikt, utvalg, kompetanse og kvalitetsvurdering (tabell 1). 
Tabell 1: Artikkeloversikt og design

\begin{tabular}{|c|c|c|c|c|}
\hline Review & Hensikt & Utvalg & Kompetanse & Kvalitetsvurdering \\
\hline $\begin{array}{l}\text { Pinto, 2013, } \\
\text { Spania }\end{array}$ & $\begin{array}{l}\text { Unders } ø \text { ke pasien- } \\
\text { terfaring med } \\
\text { KOLS-rehabilitering }\end{array}$ & 106 pasienter & $\begin{array}{l}\text { Kommunikasjon, } \\
\text { psykososial støtte, } \\
\text { diagnoserelatert } \\
\text { kunnskap }\end{array}$ & $\mathrm{H} \varnothing \mathrm{y}$ \\
\hline Mixed method & Hensikt & Utvalg & Kompetanse & Kvalitetsvurdering \\
\hline $\begin{array}{l}\text { Scala, 2008, } \\
\text { Italia }\end{array}$ & $\begin{array}{l}\text { Studere effekten } \\
\text { av tiltak på reduks- } \\
\text { jon av blodtrykk/ } \\
\text { hypertensjon }\end{array}$ & 150 pasienter & $\begin{array}{l}\text { Kommunikasjons-fer- } \\
\text { digheter, støtte/ en- } \\
\text { drings-veiledning, } \\
\text { gruppeleder }\end{array}$ & Middels \\
\hline $\begin{array}{l}\text { Jones, 2011, } \\
\text { Canada }\end{array}$ & $\begin{array}{l}\text { Måle lærings-ut- } \\
\text { bytte etter } \\
\text { deltakelse på } \\
\text { helsepedagogisk } \\
\text { opplæring ang. } \\
\text { lærings- og me- } \\
\text { stringstilbud for } \\
\text { kreftpasienter }\end{array}$ & 98 deltakere & $\begin{array}{l}\text { Pedagogiske } \\
\text { kunnskaper, } \\
\text { kunnskaper om me- } \\
\text { stringsstrategier, skape } \\
\text { trygge rammer for } \\
\text { deltakere }\end{array}$ & Middels \\
\hline $\begin{array}{l}\text { Butow, 2005, } \\
\text { Australia }\end{array}$ & $\begin{array}{l}\text { Undersøke } \\
\text { kurslederes syn på } \\
\text { kompetansebehov } \\
\text { ved gruppetilbud til } \\
\text { kreftpasienter }\end{array}$ & 179 ledere & $\begin{array}{l}\text { Pedagogisk kunnskap, } \\
\text { veilednings-kom- } \\
\text { petanse, } \\
\text { personlige egenskaper } \\
\text { og holdninger }\end{array}$ & Middels \\
\hline Kvantitativ & Hensikt & Utvalg & Kompetanse & Kvalitetsvurdering \\
\hline $\begin{array}{l}\text { Gagliardino, 2007, } \\
\text { Argentina }\end{array}$ & $\begin{array}{l}\text { Evaluere master- } \\
\text { utdanning i diabe- } \\
\text { tesopplæring }\end{array}$ & 20 studenter & $\begin{array}{l}\text { Medisinsk kunnskap, } \\
\text { pedagogikk, } \\
\text { kommunikasjon, støt- } \\
\text { tende holdninger }\end{array}$ & Mangelfull \\
\hline $\begin{array}{l}\text { Håkanson, 2012, } \\
\text { Sverige }\end{array}$ & $\begin{array}{l}\text { Se på pasient-erfa- } \\
\text { ring med gruppe- } \\
\text { basert lærings- og } \\
\text { mestringstilbud for } \\
\text { personer med irri- } \\
\text { tabel tarmsyndrom }\end{array}$ & 31 pasienter & $\begin{array}{l}\text { Medisinsk kunnskap, } \\
\text { skape trygge rammer } \\
\text { og tilrettelegge for } \\
\text { gjensidig kommunikas- } \\
\text { jon }\end{array}$ & $\mathrm{H} \varnothing \mathrm{y}$ \\
\hline Kvalitativ & Hensikt & Utvalg & Kompetanse & Kvalitetsvurdering \\
\hline $\begin{array}{l}\text { Adolfsson, 2008, } \\
\text { Sverige }\end{array}$ & $\begin{array}{l}\text { Unders } \varnothing \text { ke pasien- } \\
\text { terfaring med } \\
\text { gruppebasert } \\
\text { og individbasert } \\
\text { lærings- og } \\
\text { mestringstilbud }\end{array}$ & 28 pasienter & $\begin{array}{l}\text { Aksepterende hold- } \\
\text { ning, mestre gruppe- } \\
\text { lederrollen }\end{array}$ & $\mathrm{H} \varnothing \mathrm{y}$ \\
\hline $\begin{array}{l}\text { Jormfeldt, 2013, } \\
\text { Sverige }\end{array}$ & $\begin{array}{l}\text { Unders } ø \text { ke fagper- } \\
\text { soners erfaringer } \\
\text { med gruppeledelse }\end{array}$ & 4 fagpersoner & $\begin{array}{l}\text { Ferdigheter innen } \\
\text { gruppeledelse og invol- } \\
\text { vering av deltakere }\end{array}$ & Middels \\
\hline $\begin{array}{l}\text { Dysvik, 2010, } \\
\text { Norge }\end{array}$ & $\begin{array}{l}\text { Utvikle retnings-lin- } \\
\text { jer for veiledning av } \\
\text { smertepasienter }\end{array}$ & 9 veiledere & $\begin{array}{l}\text { Medisinsk kunnskap, } \\
\text { veilednings-kom- } \\
\text { petanse i gruppe og } \\
\text { én-til-én }\end{array}$ & Middels \\
\hline $\begin{array}{l}\text { Wilson, 2007, } \\
\text { Irland }\end{array}$ & $\begin{array}{l}\text { Undersøke syn på } \\
\text { mestringstiltak } \\
\text { blant pasienter og } \\
\text { fagpersoner }\end{array}$ & $\begin{array}{l}32 \text { pasienter og } \\
8 \text { fagpersoner }\end{array}$ & $\begin{array}{l}\text { Gruppeledelse, kom- } \\
\text { munikasjons-fer- } \\
\text { digheter }\end{array}$ & $\mathrm{H} \varnothing y$ \\
\hline $\begin{array}{l}\text { Svavarsdóttir, 2014, } \\
\text { Norden }\end{array}$ & $\begin{array}{l}\text { Undersøke syn på } \\
\text { kompetanse/tiltak } \\
\text { for hjertepasienter }\end{array}$ & 19 fagpersoner & $\begin{array}{l}\text { Medisinsk, pedagogikk, } \\
\text { kommunikasjons- } \\
\text { ferdigheter }\end{array}$ & Middels \\
\hline $\begin{array}{l}\text { Costello, 2013, } \\
\text { USA }\end{array}$ & $\begin{array}{l}\text { Undersøke mest- } \\
\text { rings-strategier }\end{array}$ & 6 gruppeledere & $\begin{array}{l}\text { Medisinsk kunnskap, } \\
\text { gruppeledelse }\end{array}$ & Middels \\
\hline $\begin{array}{l}\text { Andersen, 2014, } \\
\text { Danmark }\end{array}$ & $\begin{array}{l}\text { Undersøke fagper- } \\
\text { soners erfaringer } \\
\text { med gjennomføring } \\
\text { av lærings- og me- } \\
\text { stringstilbud }\end{array}$ & 11 fagpersoner & $\begin{array}{l}\text { Medisinsk kunnskap, } \\
\text { gruppeleder, peda- } \\
\text { gogikk }\end{array}$ & Middels \\
\hline $\begin{array}{l}\text { Sekse, 2014, } \\
\text { Norge }\end{array}$ & $\begin{array}{l}\text { Unders } ø \text { ke bryst- } \\
\text { kreft-pasienters } \\
\text { erfaringer med } \\
\text { gruppebasert } \\
\text { lærings- og me- } \\
\text { stringstilbud }\end{array}$ & 17 pasienter & $\begin{array}{l}\text { Skape trygge omgiv- } \\
\text { elser, gruppeledelse, } \\
\text { kunnskaper om me- } \\
\text { stringsstrategier, } \\
\text { medisinsk kunnskap }\end{array}$ & Middels \\
\hline $\begin{array}{l}\text { Dures, 2014, } \\
\text { UK }\end{array}$ & $\begin{array}{l}\text { Revmatologers } \\
\text { oppfatninger og } \\
\text { erfaringer med et } \\
\text { helsepedagogisk } \\
\text { opplæringstiltak }\end{array}$ & 16 fagpersoner & $\begin{array}{l}\text { Ferdigheter innen kog- } \\
\text { nitiv atferdsterapi og } \\
\text { kommunikasjon } \\
\text { (rettet mot endrings- } \\
\text { arbeid) }\end{array}$ & Middels \\
\hline $\begin{array}{l}\text { Furnes, 2014, } \\
\text { Norge }\end{array}$ & $\begin{array}{l}\text { Unders } \varnothing \text { ke pasient- } \\
\text { ers oppfatning av } \\
\text { viktige aspekter } \\
\text { ved gruppebasert } \\
\text { lærings- og me- } \\
\text { stringstilbud }\end{array}$ & 34 pasienter & $\begin{array}{l}\text { Gruppeleder skaper } \\
\text { trygghet og tilretteleg- } \\
\text { ger for erfarings- } \\
\text { utveksling }\end{array}$ & Middels \\
\hline
\end{tabular}




\section{RESULTAT}

De fleste inkluderte studiene tar for seg fagpersoners $(15,22-27)$ og pasienters oppfatninger (28-34) av viktig kompetanse hos fagpersoner som tilbyr lærings- og mestringstilbud. Én studie omhandler begge gruppene (33). Det totale antallet pasienter som er omtalt i studiene av pasientoppfatninger, er 398. Pasientene har type 2-diabetes (34), kroniske smerter $(25,28)$, kreft $(31)$, KOLS $(29,33)$, irritabel tarmsyndrom (32) og hypertensjon (30). Det totale antallet fagpersoner som er omtalt i studiene om kompetanseoppfatninger, er 252. Profesjonene som oftest blir beskrevet i disse studiene, er leger, sykepleiere, fysioterapeuter, ergoterapeuter og ernæringsfysiologer.

De fleste studiene er kvalitative empiriske studier (22-28, 31-34). Én studie er en systematisk oversikt over kvalitative studier (29) og tre har en mixed method-design (15, 30, 36). To studier undersøker ved hjelp av kvantitative data hvilken innvirkning helsepedagogiske opplæringstiltak har på tilegnelsen av kunnskaper, ferdigheter og holdninger til personer som planlegger å gi opplæring og lærings- og mestringstilbud (35, 36). De 16 inkluderte studiene belyser altså kompetanse fra ulike synsvinkler. Ikke alle problemstillingene i studiene hadde kompetanse som tema, men tok opp spørsmålet i presentasjonen av studienes resultater

\section{KOMPETANSEOMRÅDER}

Innholdsanalysen av de 16 studiene viser at det er seks kompetanseområder som fremheves som de mest sentrale for fagpersoners kompetanse. Disse områdene vektlegges på tvers av de ulike studiedesignene og problemstillingene. De seks kompetanseområdene er følgende:

- gruppeledelse

- medisinsk fagkunnskap om diagnose og behandling

- kommunikasjon

- mestring og mestringsstrategier

- pedagogikk

- personlige egenskaper og holdninger

\section{GRUPPELEDELSE}

Hele tolv av de 16 studiene understreker at det er viktig å kunne lede grupper av pasienter og brukere for å tilrettelegge for læring og mestring på en adekvat måte $(15,22,24,25$, 27-34, 36). Studiene beskriver i hovedsak to dimensjoner ved gruppeledelse. Den første gjelder fagpersonenes evne til å skape trygge og støttende omgivelser for gruppedeltakere på lærings- og mestringstilbud. Et eksempel på det er å oppfordre til deltakelse og få pasienter til å kjenne seg velkommen, sett og hørt $(15,24)$.

Den andre dimensjonen vedrører fagpersoners evne til å stimulere til aktiv gruppedeltakelse, læring og erfaringsutveksling ved hjelp av ulike verktøyer og metoder. Det kan for eksempel være gjennom spørsmål og kommentarer som oppfordrer hver enkelt og hele gruppen til å dele tanker og følelser knyttet til egen livssituasjon. Flere studier av pasienterfaringer st $\varnothing t t e r$ opp under viktigheten av aktive gruppediskusjoner. En diabetespasient uttrykte seg slik: "Being able to hear how they [andre diabetespasienter] experience their disease, the tricks and solutions they have for food and exercise, it is so important.» (34). Samtidig peker flere av studiene på at fagpersoner opplever at de mangler kompetanse i å lede slike gruppeprosesser på en god måte.

\section{FAGKUNNSKAP}

Åtte studier understreket at det er viktig at fagpersoner har faglig medisinsk kunnskap. De må også være oppdatert på forskning og kunnskap om spesifikke diagnoser, behandling og 
egenbehandling for personer som har langvarige helseutfordringer (15, 24-27, 29, 31, 32, 35). Hovedbegrunnelsen i studiene for å hevde at fagkunnskap spiller en viktig rolle, er at pasienter, brukere og pårørende skal kunne få grunnleggende kunnskap om egen sykdom. En sykepleier forteller det slik: «Of course the patients need medical knowledge. Knowledge they [pasientene] can hopefully use as a driver in the process of getting a healthier lifestyle.» (24). Samtidig rapporterer flere fagpersoner i studiene om utfordringer med å tilpasse språkbruk og faglig kunnskapsnivå til varierte pasientgrupper med ulik bakgrunn og med ulike behov.

\section{KUNNSKAP OM KOMMUNIKASJON}

Åtte studier omtalte kunnskaper og ferdigheter innen kommunikasjon som et viktig kompetanseområde $(15,23,26,30,32,33,35,36)$. Studiene beskriver generelle kommunikasjonsferdigheter som er mye anvendt i samhandling mellom helsearbeidere og pasienter, som for eksempel aktiv lytting og det å snakke forståelig. I tillegg beskriver de ferdigheter som er nærmere knyttet til det å starte, opprettholde og avslutte gruppediskusjoner mellom pasienter eller brukere. Eksempler kan være hvordan man kan kommunisere verbalt for å skape en trygg atmosfære og trygge omgivelser, hvordan man kan legge til rette for at personer kan reflektere og diskutere vaner og tankemønstre, og hvordan man kan håndtere en negativ gruppedynamikk. Slik sett er det en nær sammenheng mellom kunnskaper og ferdigheter innen kommunikasjon og gruppeledelse.

\section{KUNNSKAP OM MESTRING}

Åtte studier viser til at kunnskap om mestring og mestringsprosesser er sentrale for at pasienter og brukere skal få utbytte av å delta i lærings- og mestringstilbud $(15,23,25,30$, $31,35,36)$. Studiene omtaler hvilken nytte det har at fagpersoner og kursledere formidler praktisk kunnskap om mestring, mestringsstrategier, og om hvordan de kan løse praktiske utfordringer i hverdagen. I tillegg peker de på viktigheten av at kursledere kan anvende metoder og teknikker som setter i gang og støtter opp under endringer i tanke- og handlingsmønstre hos pasienter og brukere. Eksempler på dette er ved å bygge på og anerkjenne gruppedeltakeres egne mestringsressurser, eller ved å skape refleksjon og diskusjon blant deltakerne. En kreftpasient sa følgende om hvor viktig dette var: «I don't think the outcome would have been the same if we had just sat and talked with each other [without nurses] ... That would have been more of a self-pitying group.» (31)

\section{PEDAGOGISKE KUNNSKAPER}

Seks av studiene poengterer at pedagogiske kunnskaper og ferdigheter er et grunnleggende kompetanseområde for fagpersoner som tilbyr lærings- og mestringstilbud (15, 24, 26, 35-37). Studiene understreker to hoveddimensjoner ved slike kunnskaper og ferdigheter. For det første trengs det kunnskap om læring som fenomen og hvordan man anvender teoretisk kunnskap i lærings- og mestringstilbud. Det er også behov for kunnskap om hvordan man tilpasser og justerer undervisningen eller læringsaktiviteter til de kunnskapsog undervisningsbehovene deltakerne har. I tillegg vektlegger flere at det er nødvendig å ha grunnleggende praktiske kunnskaper og ferdigheter i hvordan man kan planlegge, organisere, gjennomføre og evaluere kurs og tilbud for pasienter og brukere.

\section{PERSONLIGE EGENSKAPER OG HOLDNINGER}

Pasienter, fagpersoner og forskere peker på at personlige egenskaper, holdninger og verdier hos helsepersonell har betydning for hvordan pasienter og brukere opplever å delta på lærings- og mestringstilbud, enten det er i positiv eller i negativ forstand. To studier tar opp dette $(26,35)$. Pasientene i disse studiene beskriver disse egenskapene som forutsetninger for måten helsepersonell handler på og møter dem på. Pasienter og brukere legger vekt på fagpersonenes evne til å vise omsorg, empati, interesse, respekt og til å utvise ikke-dømmende holdninger overfor personer som har langvarige helseutfordringer. Disse 
egenskapene omtales som viktige av flere grunner. De har positiv innflytelse på relasjoner som etableres mellom helsearbeider og pasient, på pasientenes motivasjon for å delta på slike tilbud, og på pasientenes opplevelse av støtte og forståelse for sine helsemessige utfordringer.

\section{DISKUSJON}

Utdanningsinstitusjoner, fagpersoner, brukerrepresentanter og pasienter har i lang tid understreket at kompetansen og de personlige egenskapene til fagpersoner som holder lærings- og mestringstilbud, er avgjørende for kvaliteten på slike tilbud (39). Likevel har det vært uklart hvilken kompetanse som er mest relevant for å bidra til best mulig utbytte av å delta på tilbud.

Gjennom systematiske litteraturs $\varnothing \mathrm{k}$ har vi i denne oversikten beskrevet tilgjengelig litteratur om hvilken kompetanse man anser som viktigst hos fagpersoner som gir lærings- og mestringstilbud til pasienter og brukere som har langvarige helseutfordringer. I litteraturen presiserer både fagpersonene selv, og pasienter og brukere, at visse trekk ved fagpersonene er avgjørende for å få et positivt utbytte av opplæring og lærings- og mestringstilbud. Den kvaliteten som sies å være mest sentral hos en fagperson, er evnen til å lede og bidra til gode gruppeprosesser. Det er dessuten viktig å ha faglig og oppdatert medisinsk kunnskap om diagnose og behandling, kommunikasjonsferdigheter, mestring, pedagogiske ferdigheter og personlige egenskaper og holdninger (se faktaboks).

Resultatene er naturlig nok i tråd med sykepleiefaglig, medisinsk og psykologisk litteratur om behandler-pasientkommunikasjon, men avdekker også kunnskap som har lett for å bli underkommunisert. Et godt eksempel er forskning innen psykoterapi samt forskning på terapeutiske metoder. Flere tiår med forskning har vist at personlige forskjeller mellom terapeuter har større betydning for utfallet hos klientenes eller pasientenes psykiske helse, enn forskjeller i de metodene terapeutene benytter (12-14). Forskning med og uten eksperimentell design underst $\varnothing$ tter dette. Denne problematikken ble i lengre tid oversett i et fagfelt som var dominert av effektstudier, og som i stor grad skjulte bakenforliggende variabler (14).

Den kvaliteten som sies å være mest sentral hos en fagperson, er evnen til å lede og bidra til gode gruppeprosesser.

Studier av hvilken betydning fagpersoners egenskaper har for utbyttet ved å delta på lærings- og mestringstilbud (utøvereffekter), er imidlertid en mangelvare. Dessuten har studier som indirekte tematiserer utøvereffekten ved å undersøke viktig kompetanse hos fagpersoner, fått lite oppmerksomhet (9). I denne systematiske oversikten fant vi 16 studier som tilfredsstilte inklusjonskriteriene og beskrev ulike kompetanseområder. Noen av disse hadde ikke kompetanse som problemstilling for studien, men tok opp temaet i omtalen av resultatene. Gjennomgangen viser videre at det er et flertall av kvalitative studier. En begrensning ved de kvalitative studiene er at funnene ikke lar seg generalisere til andre populasjoner. Også artikkelforfatterne diskuterer dette.

De fleste studiene vi har beskrevet, er dessuten basert på kvalitative intervjuer. Slike data egner seg dårlig til å belyse hvordan kunnskap, ferdigheter og holdninger faktisk og helt konkret utøves av dem som gir lærings- og mestringstilbud. Dataene gir heller ikke informasjon om hvordan ulike typer kompetanse kombineres og integreres i de enkelte tilbudene, og hvilken effekt kompetanse har på ulike utfallsmål (26). Det er behov for flere etnografiske studier og effektstudier med eksperimentell design for å kunne belyse disse spørsmålene. Kvaliteten på de fleste studiene ble dessuten vurdert som middels. Vi vurderte 
at tolv av 16 studier var av middels kvalitet, tre studier var av høy kvalitet, og én var mangelfull. Kunnskapssenteret definerer «middels kvalitet» som at det er lite sannsynlig at studienes konklusjon påvirkes av manglene i studiene, men at vi likevel må ta forbehold før vi kan trekke entydige konklusjoner.

\section{IMPLIKASJONER}

Resultatene fra denne studien beskriver sentrale kompetanseområder for fagpersoner som gir lærings- og mestringstilbud. Så vidt vi kjenner til, har det ikke tidligere blitt foretatt systematiske $s \varnothing \mathrm{k}$ etter slik litteratur.

Litteraturgjennomgangen viser likevel at det er behov for mer forskning på temaet. Det er behov for flere typer kvalitative studier for å øke forståelsen for hvordan kompetanseområder relaterer seg til hverandre og knyttes sammen i konkrete lærings- og mestringstilbud. I tillegg trengs det kvantitative studier for å forstå hvordan kompetansen til fagpersonene påvirker ulike pasientutfall. Det er også behov for å foreta studier av viktige kunnskaper, ferdigheter og holdninger hos brukerrepresentanter, som ofte er medtjenesteytere i lærings- og mestringstilbud. Slike studier er nødvendige for å øke relevansen av forskningen i en norsk kontekst. Kompetansen til brukerrepresentanter vil på noen områder være overlappende med fagpersonenes kompetanse, især de ferdighetene som kreves for å kunne samarbeide godt med pasienter og brukere (39).

Inkluderte studier viser også at fagpersoner er usikre på egen kompetanse.

En bedre innsikt i hvilke kompetanseområder som er nødvendige i opplæring og lærings- og mestringstilbud, kan gi viktige innspill til dem som er ansvarlige for kurs i helsepedagogikk for fagpersoner i spesialisthelsetjenesten og den kommunale helse- og omsorgstjenesten. En slik innsikt kan også gi viktige innspill til de fagpersonene og brukerrepresentantene som tilbyr lærings- og mestringstilbud for pasienter og brukere (26).

Inkluderte studier viser også at fagpersoner er usikre på egen kompetanse $(15,24)$. Flere understreker derfor viktigheten av å forbedre helsepedagogiske tilbud. Formålet til slike tilbud er å tilføre fagpersoner og brukerrepresentanter som holder lærings- og mestringstilbud, kunnskap om hvordan de kan legge til rette for læring og mestring hos pasienter, brukere og pårørende (39).

\section{METODEKRITIKK}

Lærings- og mestringstilbudene som studiene tar utgangspunkt i, tilbys av fagpersoner. Studiene beskriver altså ikke nødvendig kompetanse knyttet til det å legge til rette for reell brukermedvirkning og et sidestilt samarbeid med brukerrepresentanter i planlegging, gjennomføring og evaluering av tiltak eller tilbud. I en norsk kontekst utgjør en slik samarbeidsmodell en sentral ramme for lærings- og mestringstilbud (39).

I tillegg beskriver studiene nokså få diagnosegrupper. Det er rimelig at kompetansebehovet vil variere mellom ulike tiltak og ulike diagnosegrupper (26). Studiene tar utgangspunkt i ulike typer lærings- og mestringstilbud for ulike diagnosegrupper og belyser kompetansespørsmålet fra ulike synsvinkler. Likevel vektlegger de langt på vei de samme kompetanseområdene.

En av fordelene ved en systematisk litteraturstudie er at det anvendes en systematisk og presist beskrevet fremgangsmåte for å finne og gi en oversikt over aktuell forskning. En svakhet ved studiene vi har oppsummert, er at de fleste er kvalitative studier med et begrenset antall pasienter og diagnoser. I tillegg har de varierende kvalitet. Alle studiene har 
heller ikke som primær problemstilling å unders $\emptyset$ ke kompetanse. Et viktig formål med denne systematiske oversikten har imidlertid vært å få oversikt over hvilke typer studier som finnes da forskning på området er begrenset.

Gjennomgangen viser også at en rekke felles kompetanseområder blir vektlagt på tvers av studiedesign, diagnosegrupper og intervensjoner, noe som kan tyde på at områdene som beskrives, kan utgjøre grunnkomponenter i helsepedagogisk kompetanse. En svakhet ved litteraturoversikten er at bare én person, førsteforfatter, gjennomgikk og ekskluderte potensielt relevante artikler i fulltekst, i tillegg til å ekstrahere informasjon fra 17 foreløpig inkluderte studier. Det at utvelgelsesprosess og datainnhenting ikke ble foretatt av minst to personer uavhengig av hverandre, øker sannsynligheten for skjevhet (bias). Det kan dermed ha hatt konsekvenser for tolkningen av resultatene.

\section{KONKLUSJON}

Vår litteraturgjennomgang tyder på at helsepersonell trenger kunnskap og ferdigheter innen gruppeledelse, diagnoser, kommunikasjon, mestring, pedagogikk samt egnete personlige egenskaper og holdninger for å kunne gi gode gruppebaserte lærings- og mestringstilbud. Det finnes relativt få studier av kompetansen til fagpersoner som gir opplæring, og læringsog mestringstilbud, og det har manglet systematiske litteraturgjennomganger. Vår studie bør derfor kunne gjøre denne kunnskapen mer tilgjengelig.

Resultatene må likevel anvendes med varsomhet. De fleste omtalte studier er av middels kvalitet, noe som betyr at det er lite sannsynlig at studienes konklusjoner påvirkes av manglene. Vi må likevel ta forbehold før vi kan trekke entydige konklusjoner. Det er behov for flere kvalitativt gode studier på temaet med større utvalg og eksperimentell design. Det er også behov for å styrke kvaliteten ytterligere på helsepedagogiske opplæringstiltak og utdanning av studenter, fagpersoner og brukerrepresentanter.

\section{REFERANSER}

1. Folkehelserapporten 2014. Helsetilstanden i Norge. Nasjonalt folkehelseinstitutt.

2. Meld. St. 26 (2014--2015). Fremtidens primærhelsetjeneste - nærhet og helhet.

3. Fønhus M, Stenberg U, Hafstad E. Mestringstiltak med brukermedvirkning for personer som har langvarige helseutfordringer. Oslo: Nasjonalt kunnskapssenter for helsetjenesten. 2015.

4. Zwerink M, Brusse-Keizer M, van der Valk PD, Zielhuis GA, Monninkhof EM, van der Palen J et al. Self management for patients with chronic obstructive pulmonary disease. The Cochrane database of systematic reviews. 2014;3:Cd002990.

5. Ahn S, Basu R, Smith M, Jiang L, Lorig K, Whitelaw N et al. The impact of chronic disease self-management programs: healthcare savings through a community-based intervention. BMC Public Health 2013;13(1).

6. Fønhus M, Dahm K. Cochrane: mestringstiltak for personer med kols. Sykepleien Forskning 2015;10(2):110-1. Tilgjengelig fra: https://sykepleien.no/forskning/2015/07/mestringstiltak-personer-med-kols . (Nedlastet 18.11.2016).

7. Fønhus M. Mestringskurs - hva har form og innhold og si for utbyttet? Oslo: NK LMH. 2013.

8. Barlow J, Wright C, Sheasby J, Turner A, Hainsworth J. Self-management approaches 
for people with chronic conditions: a review. Patient Education and Counseling.

2002;48(2):177-87.

9. Anderson RM, Funnell MM. The art and science of diabetes education: a culture out of balance. Diabetes Educ. 2008;34(1):109-17.

10. Koster T, Granum V. Lærer å formidle kunnskap. Sykepleien 2009;10:64-7.

Tilgjengelig fra: https://sykepleien.no/forskning/2009/06/laerer-formidle-kunnskap.

(Nedlastet 18.11.2016).

11. Hvinden K. Etablering av lærings- og mestringssentra - Historie, grunnlagstenkning, innhold og organisering. I: Lerdal A, Fagermoen M (red.). Læring og mestring - et helsefremmende perspektiv i praksis og forskning. Oslo: Gyldendal Akademisk. 2012. p. 48-62.

12. Silverman J, Kurtz, S., Draper, J. Skills for communicating with patients. Oxford: Radcliffe Publishing. 2005.

13. Bramhall E. Effective communication skills in nursing practice. Nursing standard (Royal College of Nursing (Great Britain): 1987). 2014;29(14):53-9.

14. Rønnestad M. Evidensbasert praksis i psykologi. Tidsskrift for Norsk Psykologforening 2008;45(4):444-54.

15. Butow P, Ussher J, Kirsten L, Hobbs K, Smith K, Wain G et al. Sustaining leaders of cancer support groups. Social Work in Health Care 2006;42(2):39-55.

16. Håndbok for Nasjonalt kunnskapssenter for helsetjenesten. Slik oppsummerer vi forskning. 2015. Tilgjengelig fra: http://www.kunnskapssenteret.no/verktoy/slik-oppsummerer-vi-forskning (Nedlastet 01.02.2016).

17. Hatlevik I. Meningsfulle sammenhenger. En studie av sammenhenger mellom læring pa? ulike arenaer og utvikling av ulike aspekter ved profesjonell kompetanse hos studenter $\mathrm{i}$ sykepleier-, lærer- og sosialarbeider- utdanningene. Oslo: Høgskolen i Oslo og Akershus. 2014.

18. Skau G. Gode fagfolk vokser. Personlig kompetanse i arbeid med mennesker. 4. utgave. Oslo: Cappelen Damm Akademisk. 2011.

19. Henriksen J, Vetlesen A. Nærhet og distanse. Grunnlag, verdier og etiske teorier i arbeid med mennesker. Oslo: Gyldendal. 2000.

20. Grabowski D, Brun Jensen B, Willaing I, Zoffmann V, Schiøtz M. Sundhedspædagogik i patientutddannelse. En litteraturbaseret gennemgang af udvalgte sundhedspædagogiske begrebers anvendelse i patientuddannelse. Steno Center for sundhedsfremme. 2010.

21. Wilkinson S. Focus group research. I: Silverman D (red.). Qualitative research Theory, Method and Practice. 2. utg.. London: Sage. 2006. p. 177-99.

22. Jormfeldt $H$, Brunt DA, Rask M, Bengtsson A, Svedberg P. Staff's experiences of a person-centered health education group intervention for people with a persistent mental illness. Issues in Mental Health Nursing. 2013;34(7):488-96. 
23. Dures E, Hewlett S, Ambler N, Jenkins R, Clarke J, Gooberman-Hil R. Rheumatology clinicians' experiences of brief training and implementation of skills to support patient self-management. BMC Musculoskeletal Disorders. 2014;15(108).

24. Andersen TH, Hempler NF, Willaing I. Educator challenges using participatory methods in group-based patient education. Health Education 2014;114(2):152-65.

25. Dysvik E, Stephens P. Conducting rehabilitation groups for people suffering from chronic pain. International Journal of Nursing Practice. 2010;16(3):233-40.

26. Svavarsdottir MH, Sigurethardottir AK, Steinsbekk A. Knowledge and skills needed for patient education for individuals with coronary heart disease: The perspective of health professionals. European Journal of Cardiovascular Nursing : Journal of the Working Group on Cardiovascular Nursing of the European Society of Cardiology 2014.

27. Costello JF. Roles and strategies of diabetes support group facilitators: An exploratory study. The Diabetes Educator 2013;39(2):178-86.

28. Furnes B, Natvig G, Dysvik E. Therapeutic elements in a self-management approach: experiences from group participation among people suffering from chronic pain. Patient Preference and Adherence 2014;8:1085-92.

29. de Sousa Pinto JM, Martin-Nogueras AM, Morano MT, Macedo TE, Arenillas JI, Troosters T. Chronic obstructive pulmonary disease patients' experience with pulmonary rehabilitation: a systematic review of qualitative research. Chronic Respiratory Disease. 2013;10(3):141-57.

30. Scala D, D'Avino M, Cozzolino S, Mancini A, Andria B, Caruso G et al. Promotion of behavioural change in people with hypertension: an intervention study. Pharm World Sci. 2008;30(6):834-9.

31. Sekse RJT, Blaaka G, Buestad I, Tengesdal E, Paulsen A, Vika M. Education and counselling group intervention for women treated for gynaecological cancer: does it help? Scandinavian Journal of Caring Sciences. 2014;28(1):112-21.

32. Hakanson C, Sahlberg-Blom E, Ternestedt BM, Nyhlin H. Learning to live with irritabel bowel syndrome. The influence of a group-based patient education programme on peoples' ability to manage illness in everyday life. Scandinavian Journal of Caring Sciences 2011;25(3):491-8.

33. Wilson JS, O'Neill B, Reilly J, MacMahon J, Bradley JM. Education in pulmonary rehabilitation: The Patient's Perspective. Archives of Physical Medicine and Rehabilitation 2007;88(12):1704-9.

34. Adolfsson ET, Starrin B, Smide B, Wikblad K. Type 2 diabetic patients' experiences of two different educational approaches - A qualitative study. International Journal of Nursing Studies 2008;45(7):986-94.

35. Gagliardino JJ, Malbrán MdC, Clark C. Development and implementation of advanced training course for diabetes educators in Argentina. Diabetes Spectrum 2007;20(1):24-30.

36. Jones JM, Papadakos J, Bennett C, Blacker S, Catton P, Harth T et al. Maximizing your Patient Education Skills (MPES): A multi-site evaluation of an innovative patient education 
skills training course for oncology health care professionals. Patient Education and Counseling 2011;84(2):176-84.

37. Rodgers J. Guidance on delivering effective group education. British Journal of Community Nursing 2006;11(11):476-82.

38. Lawn S, Schoo A. Supporting self-management of chronic health conditions: Common approaches. Patient Education and Counseling 2010;80(2):205-11.

39. Hvinden K. Etablering av lærings- og mestringssentra - Historie, grunnlagstenkning, innhold og organisering. I: Lerdal A, Fagermoen M (red.). Læring og mestring - et helsefremmende perspektiv i praksis og forskning. Oslo: Gyldendal Akademisk. 2012. p. 48-62. 